

\title{
Pattern of haemostatic parameters and their relationship with microalbuminuria among hypertensives in Northern Nigeria Ijei IP*1, Bello-Manga $\mathrm{H}^{1}$, Yusuf $\mathrm{R}^{2}$, Sani $\mathrm{BG}^{3}$, Mamman $\mathrm{AI}^{4}$
}

1Department of Haematology and Blood Transfusion, Kaduna State University, Kaduna, Nigeria ${ }^{2}$ Department of Chemical Pathology, ${ }^{3}$ Department of Internal Medicine, ${ }^{4}$ Department of Haematology and Blood Transfusion, Ahmadu Bello University, Zaria, Nigeria

\author{
*Correspondence: Dr. IP Ijei, Department of Haematology and Blood Transfusion, Kaduna State \\ University, Kaduna, Nigeria. Email: ijeiip@yahoo.com; ORCID - https://orcid.org/0000-0001-5669-2139
}

\begin{abstract}
Background: Hypertension is a common, non-communicable disorder of public health significance. Abnormalities in haemostasis and blood rheology have been linked to target organ damage (TOD) in hypertension. Microalbuminuria (MA) is an independent predictor of TOD.

Methods: A cross-sectional study was carried out among 107 consecutively recruited hypertensives attending the Cardiology Clinic at ABUTH, Zaria, Nigeria. Complete blood counts, haemostatic screening tests and microalbuminuria assay were performed on blood and urine specimens.

Results: The mean age of participants was $50.2 \pm 11.3$ years and $59.3 \pm 18.2$ years for females and males respectively with a female predominance $(91 / 107 ; 85 \%)$. The frequencies of abnormal platelet counts, prothrombin time, activated partial thromboplastin time, thrombin time, fibrinogen, D-dimer and MA were 15\%, 57\%, 54.2\%, 64.5\%, 100\%, 25.2\%, and $41 \%$ respectively. Participants with poor BP control had an increased risk of derangements in aPTT and platelet counts $(\mathrm{OR}=1.4,1.4)$ but there was no significant difference in means with BP for aPTT, fibrinogen, and platelets ( $p=$ $0.517,0.257$ and 0.525 respectively). The impact of the duration of hypertension was shown in D-dimer levels up to 10 years. Participants on ARB/ ACEI- containing regimens showed a higher risk of derangement in TT, aPTT, PT and Ddimer in contrast to platelet counts $(\mathrm{OR}=0.96, \mathrm{p}=0.836)$. Haemostatic parameters showed weakly positive, statistically significant correlation on regression analysis.

Conclusion: There is a high prevalence of, and positive correlation between haemostatic abnormalities and MA among hypertensives in Northern Nigeria. Abnormal haemostatic screening tests may indicate MA and increased risk of TOD.
\end{abstract}

Keywords: ACE Inhibitors, Hypertension, Haemostatic parameters, Microalbuminuria, Target Organ Damage.

\section{Introduction}

Hypertension, a disease of public health concern worldwide, is defined as systolic blood pressure of $\geq 140 \mathrm{mmHg}$ and diastolic blood pressure of $\geq 90 \mathrm{mmHg}$. [1 - 3] Hypertension is often asymptomatic and may lead to lethal complications if untreated. [1] The risk of 
cardiovascular disease and stroke increases with rising blood pressure, [2] a problem also seen in developing nations. ${ }^{[4]}$ Hypertension is common with a prevalence of $28 \%$ in Northern American countries, up to $44 \%$ in Europe ${ }^{[5]}$ and $28.9 \%$ in Nigeria, with some studies recording prevalence as high as $33.1 \%$. [6, 7] Although there are regional and racial variations in the prevalence of hypertension, [1, 5, 6] males are more often affected. [1] Hypertension is considered topical because of its myriad of complications, which are often multi-systemic and contribute to morbidity and mortality. The most significant causes of death in hypertension include heart disease, $[1,8]$ cerebrovascular accidents and renal failure. $[1,9]$

Target organ damage in hypertension has been associated with haemostatic abnormalities due to platelet and endothelial activation. [10] The processes of thrombogenesis and atherogenesis are closely linked and many components of the coagulation and fibrinolytic pathways are primary and secondary predictors of cardiovascular events and proneness to thrombosis. [10 - 12] The modalities of antihypertensive therapy include among others, diuretics, centrally acting agents, calcium channel blockers (CCBs), angiotensin-converting enzyme inhibitors (ACEIs) and angiotensin receptor blockers (ARBs) which delay the onset of complications. [1, 13] The use of standard regimens, especially ACEIs, has been associated with a reduction in cardiovascular morbidity and mortality in hypertension. [14]

Microalbuminuria (MA) is an early finding in chronic kidney disease and has been identified as an independent predictor of adverse cardiovascular events. [15] MA also correlates significantly with the presence of left ventricular hypertrophy $(\mathrm{LVH})$, retinopathy and stroke. [14, 15] The relationship between haemostatic parameters and MA has been mostly studied primarily among diabetic patients $[16,17]$ but not much is known about the relationship between MA and haemostatic parameters among hypertensives. Therefore, this study sought to determine the pattern of some haemostatic changes in hypertension and examine their relationship with the presence of microalbuminuria, duration of diagnosis and the effects of therapy.

\section{Methods}

\section{Study design}

This was a descriptive, cross-sectional, noninterventional study conducted at the Cardiology Out-Patient Clinic at the Ahmadu Bello University Teaching Hospital (ABUTH), Shika, Zaria, Nigeria. The study population comprised 107 patients who were recruited consecutively over three months after giving written, informed consent. The patients were aged 18 years and over with diagnosed hypertension and no documented or oral evidence of diabetes, pregnancy, bleeding disorders or recent acute illness.

An interviewer-administered questionnaire was used to collect data on socio-demographic parameters, risk factors for hypertension, drug treatment and duration of disease and treatment as well as physical examination findings. Automated complete blood count (CBC) was done using Sysmex KX-21N ${ }^{\circledR}$, while prothrombin time (PT), activated partial thromboplastin time (aPTT), thrombin time (TT) were carried out using a Start4 semi-automated coagulometer $^{\circledast}$. D-dimer and fibrinogen assay by Enzyme-linked Immunosorbent Assay (ELISA) and Immunoturbidimetric Microalbuminuria Assay were performed on Ethylene diamine tetra-acetic acid (EDTA) anticoagulated venous blood, citrated plasma and on-the-spot urine samples of selected participants. 


\section{Definition of terms}

Blood pressure was defined as controlled if systolic and/or diastolic blood pressure was less than $140 \mathrm{mmHg}$ and/or $90 \mathrm{mmHg}$ respectively. Uncontrolled blood pressure was defined as systolic and/or diastolic blood pressure $\geq$ $140 \mathrm{mmHg}$ and/or $\geq 90 \mathrm{mmHg}$ respectively. [18] Haematocrit, white cell counts and platelets were considered within normal ranges for males and females if they fell within $37-53 \%$ and 30 $46 \% ; 3-13.2 \times 10^{9} / 1$ and $2.7-13.2 \times 10^{9} / 1$; and $156-$ $469 \times 10^{9} / 1$ and $132-477 \times 10^{9} / 1$ respectively. [19] Values either above or below the reference ranges were categorized as deranged.

Microalbuminuria was defined as urinary albumin excretion of $30-300 \mathrm{mg} / 1$ using on-thespot obtained urine samples. [20]

The reference ranges for haemostatic variables were set at 11-14 seconds for prothrombin, 26-40 seconds for activated partial thromboplastin time and 15-19 seconds for thrombin time. Shortened or prolonged times were categorized as deranged. [21]

The normal levels of fibrinogen and D-dimers were set at 200-400 mg/dl and less than 200ng/ml respectively. [21-23]

\section{Ethical approval}

Ethical approval was obtained from the Health Research Ethics Committee (HREC) of ABUTH, Shika and informed, written consent was obtained from all the participants.

\section{Data analysis}

Data were analysed using IBM ${ }^{\circledR}$ SPSS $^{\circledR}$ Statistics software version 20.0 and Epi Info TM version 7.1.3.10. Normally distributed data were presented as means and standard deviations. Chi-Square analyses, Student's t-test and ChiSquare test for linear trend in proportions were used for comparison of categorical data, differences between the sample mean and scored categorical data respectively. The relationships between haemostatic parameters and the level of blood pressure (BP) and drug combinations were examined using odds ratios, while the correlation between haemostatic parameters and MA was examined using ChiSquare, binary logistic regression, and linear regression analysis. The level of statistical significance was set at $P$ less than 0.05 .

\section{Results}

Socio-demographics

Table I shows that the participants were predominantly female (85\%; 91/107), Hausa (50.5\%; 54/107), had no formal education (54.2\%; 58/107) and belonged to social class IV $(44.9 \% ; 48 / 107)$. The mean ages $( \pm S D)$ were $50.2 \pm 11.3$ years and $59.3 \pm 18.2$ years for females and males respectively $(p=0.003)$ and the modal age range was $40-65$ years (73.8\%).

Identified risk factors for hypertension included a positive family history $(67.3 \% ; 72 / 107)$, alcohol ingestion $(5.6 \% ; 6 / 107)$, smoking $(2.8 \% ; 3 / 107)$ and high body mass index $(62.6 \% ; 67 / 107)$ as shown in Table II. The mean systolic blood pressure for the males and females were $142 \pm 22.5 \mathrm{mmHg}$ and $133.2 \pm 18 \mathrm{mmHg}(\mathrm{p}=0.507)$. The mean diastolic blood pressure for the males and females was $94 \pm 14.9 \mathrm{mmHg}$ and $88.4 \pm 12.6 \mathrm{mmHg}$ respectively $(\mathrm{p}=0.828)$.

Summary of haematological and haemostatic findings Table III shows a summary of laboratory findings. The frequencies of abnormal platelet counts, PT, aPTT, TT, fibrinogen and D-dimer were as follows: $15 \%, 57 \%, 54.2 \%, 64.5 \%, 100 \%$ and $25.2 \%$ respectively.

There was a statistically significant difference in the means between males and females for packed cell volume $(p<0.0001)$, mean corpuscular volume $(\mathrm{p}=0.001)$, mean corpuscular haemoglobin concentration $(\mathrm{p}=$ $0.011)$ and total white cell counts $(\mathrm{p}=0.001)$ but not for mean corpuscular haemoglobin, red cell distribution width, white cell differentials and platelet counts $(\mathrm{p}=0.566, / 0.194,0.491,0.233$, 
0.979 and 0.644 respectively). Haematological parameters showed no statistically significant difference between subjects with poorly controlled and well-controlled blood pressure. Poor BP control was associated with increased risk of derangement in platelet count and aPTT.

The subjects with poorly controlled blood pressure had a reduced risk of deranged TT, PT and D-dimer levels $(\mathrm{OR}=0.8,0.5$ and 0.6 respectively). However, they had an increased risk of derangements in aPTT and platelet counts $(\mathrm{OR}=1.4$ and 1.4 respectively), though the findings were not statistically significant as shown in Table IV ( $p=0.857,0.630,0.300,0.879$ and0.531 respectively). The student's t-test showed no significant difference in mean values of blood pressure for activated partial thromboplastin time, fibrinogen levels and platelets $(\mathrm{p}=0.517,0.257$ and 0.525 respectively).

Table I: Socio-demographic characteristics, BP range and risk factors for hypertension of subjects

\begin{tabular}{|c|c|c|c|c|c|c|}
\hline \multicolumn{2}{|l|}{ Characteristics } & \multirow{2}{*}{$\begin{array}{l}\text { Female } \\
13\end{array}$} & \multirow{2}{*}{$\begin{array}{l}\% \% \\
12.1\end{array}$} & \multirow{2}{*}{$\begin{array}{l}\text { Male } \\
2\end{array}$} & \multirow{2}{*}{$\begin{array}{c}\% \\
1.9\end{array}$} & \multirow{2}{*}{$\begin{array}{l}\text { Total } \\
15\end{array}$} \\
\hline Age(years) & $<40$ & & & & & \\
\hline & $40-65$ & 71 & 66.4 & 8 & 7.5 & 79 \\
\hline & $>65$ & 7 & 6.5 & 6 & 5.6 & 13 \\
\hline \multirow[t]{4}{*}{ Tribe } & Hausa & 49 & 45.8 & 5 & 4.7 & 54 \\
\hline & Yoruba & 5 & 4.7 & 2 & 1.9 & 7 \\
\hline & Igbo & 4 & 3.7 & 2 & 1.9 & 6 \\
\hline & Others & 33 & 30.8 & 7 & 6.5 & 40 \\
\hline \multirow[t]{4}{*}{ Marital status } & Single & 2 & 1.8 & 1 & 0.9 & 3 \\
\hline & Married & 70 & 65.4 & 14 & 13.1 & 84 \\
\hline & Widowed & 19 & 17.8 & 1 & 0.9 & 20 \\
\hline & Divorced & 0 & 0.0 & 0 & 0.0 & 0 \\
\hline \multirow{4}{*}{$\begin{array}{l}\text { Educational } \\
\text { status }\end{array}$} & Primary & 11 & 10.3 & 3 & 2.8 & 14 \\
\hline & Secondary & 6 & 5.6 & 4 & 3.7 & 10 \\
\hline & Tertiary & 20 & 18.6 & 5 & 4.7 & 25 \\
\hline & No formal education & 54 & 50.5 & 4 & 3.7 & 58 \\
\hline \multirow[t]{5}{*}{ Social class } & I & 18 & 16.8 & 5 & 4.7 & 23 \\
\hline & II & 3 & 2.8 & 2 & 1.8 & 5 \\
\hline & III & 3 & 2.8 & 2 & 1.8 & 5 \\
\hline & IV & 41 & 38.3 & 7 & 6.5 & 48 \\
\hline & $\mathrm{V}$ & 26 & 24.3 & 0 & 0.0 & 26 \\
\hline \multirow[t]{4}{*}{ Occupation } & Housewife & 30 & 28.0 & 0 & 0.0 & 30 \\
\hline & Trader & 28 & 26.2 & 4 & 3.8 & 32 \\
\hline & Teacher & 10 & 9.3 & 0 & 0.0 & 10 \\
\hline & Others & 23 & 21.5 & 12 & 11.2 & 35 \\
\hline
\end{tabular}

The impact of treatment regimens and duration of hypertension on haemostatic parameters Therapeutic regimens containing ARB/ACEI combinations appeared to offer no protection against derangements in haemostatic variables, though the $\mathrm{p}$ values were $>0.05$ as shown in Table V.

The significance of the impact of the duration of hypertension on haemostatic parameters was demonstrated in D-dimers up to ten years $(\mathrm{p}=$ 
Ijei IP, et al.

$0.034)$ but not beyond $(\mathrm{p}=0.129)$. Other $(p>0.05)$ as shown in Table VI. parameters showed no significant change

Table II: Some family-related and lifestyle-related risk factors for hypertension of subjects

\begin{tabular}{|c|c|c|c|c|c|c|c|}
\hline Risk factors & & Male & $\%$ & Female & $\%$ & OR $(\mathrm{CI})^{*}$ & $P$-value \\
\hline \multirow[t]{2}{*}{ Family history of hypertension } & Yes & 10 & 62.5 & 62 & 68.1 & $0.78(0.26-2.35)$ & 0.658 \\
\hline & No & 6 & 37.5 & 29 & 35.8 & & \\
\hline \multirow{2}{*}{ Alcohol ingestion } & Yes & 3 & 18.7 & 3 & 3.7 & $6.77(1.23-37.17)$ & 0.010 \\
\hline & No & 13 & 81.3 & 88 & 96.7 & & \\
\hline \multirow{2}{*}{ History of smoking } & Yes & 2 & 12.5 & 1 & 1.1 & 12.86(1.09-151.34) & 0.010 \\
\hline & No & 14 & 87.5 & 90 & 98.9 & & \\
\hline \multirow[t]{5}{*}{ Body mass index } & Underweight & 0 & 0.0 & 5 & 5.5 & - & 0.232 \\
\hline & Normal & 8 & 50.0 & 27 & 29.7 & & \\
\hline & Overweight & 5 & 31.3 & 16 & 17.6 & $1.05(0.29-3.78)$ & 0.935 \\
\hline & Obese & 3 & 18.7 & 37 & 40.6 & $0.27(0.07-1.13)$ & 0.061 \\
\hline & Morbidly obese & 0 & 0.0 & 6 & 6.6 & - & 0.192 \\
\hline
\end{tabular}

$\mathbf{9 1 . 7 \%}$ of the patients with a positive family history had a first degree relative with hypertension while $8.3 \%$ had a second degree relative with hypertension.

*Confidence intervals within brackets

The odds of being a male with abnormal weight were 0.42 times that of being female with a confidence interval of 0.14-1.24 and p-value 0.110

Mean BMI 29.2 \pm 8.8 and 25.8 \pm 5.1 for females and males respectively $(p=0.153)$

Table III: Summary of haematological and haemostatic measurements

\begin{tabular}{lllll}
\hline Variables & Normal & Low & Raised & Mean/SD \\
\hline Haematocrit (\%) & $92(86)$ & $15(14)$ & - & $36.8 \pm 4.5$ \\
MCV (fl) & $98(91.6)$ & $6(5.6)$ & $3(2.8)$ & - \\
MCHC (pg) & $103(96.3)$ & - & $4(3.7)$ & - \\
MCH (g/l) & $70(65.4)$ & - & $37(34.6)$ & - \\
Red Cell Distribution Width (\%) & $101(94.4)$ & - & $6(5.6)$ & - \\
White blood cells (x10\%/L) & $105(98.1 \%)$ & $2(1.9 \%)$ & - & $5.8 \pm 1.4$ \\
Platelets(x10\%/L) & $91(85 \%)$ & $13(12.2 \%)$ & $3(2.8 \%)$ & $250.7 \pm 103.2$ \\
Prothrombin Time(secs) & $46(43 \%)$ & $27(25.2 \%)$ & $34(31.8 \%)$ & $16.6 \pm 11.5$ \\
Activated Partial Thromboplastin & $49(45.8 \%)$ & $37(34.6 \%)$ & $21(19.6 \%)$ & $29.8 \pm 7.5$ \\
Time (secs) & & & & \\
Thrombin Time (secs) & $38(35.5 \%)$ & $2(1.9 \%)$ & $67(62.6 \%)$ & $16.2 \pm 4.8$ \\
Fibrinogen (mg/dl) & - & $107(100 \%)$ & - & $4.3 \pm 0.2$ \\
D-dimer (ng/dl) & 80 negative & 10 positive & 17 strongly & $340.2 \pm 400.3$ \\
& $(74.8 \%)$ & $(9.3 \%)$ & positive (15.9\%) & \\
\hline
\end{tabular}

Positive correlation between microalbuminuria and 'abnormal' haemostatic variables

The prevalence of abnormal platelet counts, PT, aPTT, TT, fibrinogen, D-dimer and MA were $15 \%$ (16/107), 57\% (61/107), 54.2\% (58/107), $64.5 \%(68 / 107), 100 \% \quad(n=107), 25.2 \% \quad(27 / 107)$ and $41 \%(44 / 107)$ respectively.
Using univariate analysis, the haemostatic parameters showed no statistically significant relationship with microalbuminuria except platelet counts $(p=0.039)$ as shown in Table VI. Also, regression analysis showed a weakly positive but statistically significant correlation between haemostatic variables and 
microalbuminuria $(\mathrm{p}<0.0001)$ except $\mathrm{D}$ dimer

$(p=0.218)$ as shown in Figure 1.

Table IV: Relationship between haemostatic parameters and blood pressure

\begin{tabular}{llllll}
\hline Variables & & $\begin{array}{l}\text { Blood Pressure } \\
\text { (mmHg) }\end{array}$ & OR & $P$-value \\
\hline Thrombin Time (secs) & Deranged & 52 & 17 & 0.82 & 0.857 \\
& Normal & 30 & 8 & $(0.31-2.11)$ & \\
Activated Partial Thromboplastin Time & Deranged & 46 & 12 & 1.38 & 0.630 \\
(secs) & Normal & 36 & 13 & $(0.56-3.40)$ & \\
Prothrombin Time (secs) & Deranged & 44 & 17 & 0.54 & 0.300 \\
& Normal & 38 & 8 & $(0.21-1.40)$ & \\
Platelet count (x 109/L) & Deranged & 13 & 3 & 1.38 & 0.879 \\
& Normal & 69 & 22 & $(0.36-5.30)$ & \\
D-dimer (ng/ml) & Deranged & 19 & 8 & 0.64 & 0.531 \\
& Normal & 63 & 17 & $(0.24-1.72)$ & \\
\hline
\end{tabular}

OR indicates Odds Ratio; (Confidence interval) Deranged denotes prolonged or shortened times; raised or low counts

\section{Discussion}

The growing burden of hypertension in Nigeria and its attendant complications contribute to its public health and socioeconomic significance worldwide. A better understanding of the associated risks and contributions to morbidity and mortality should improve clinical outcomes. The present study demonstrates a high prevalence of MA in hypertension $(41 \%)$ which is comparable to $37.5 \%$ and $54.3 \%$ in other studies among non-diabetic hypertensive patients and among diabetic hypertensives, values as high as $71.8 \%$ have been found. [24, 25] This was regardless of the method of urine collection (on-the-spot, early morning or 24hour collection) or technique of determining microalbuminuria. [24- 27]

The correlation between the presence of MA and other indicators of target organ damage (TOD) such as left ventricular hypertrophy (LVH), hypertensive retinopathy, chronic kidney disease, and stroke has been established in different studies [14, 15] and it serves as an independent predictor of adverse cardiovascular events. Unfortunately, MA is not routinely screened for in our environment. Data correlating haemostatic parameters directly with MA in hypertension are scarce. [28] The present study, to the best of the authors' knowledge, is the first of its kind in the study population, correlating commonly used haemostatic screening tests with the presence of microalbuminuria (MA) among hypertensive patients in Northern Nigeria.

Therefore, the present study contributes to the well of knowledge attempting to establish the relationships between parameters in hypertension, which may have therapeutic potential. Many studies have demonstrated the relationship between haemostasis and MA but they have been conducted primarily among diabetic patients. $[16,17]$ 
Ijei IP, et al.

Table V: Relationship between commonly used antihypertensive regimens and haemostatic parameters

\begin{tabular}{|c|c|c|c|c|c|}
\hline \multirow[t]{2}{*}{ Variables } & & \multicolumn{2}{|c|}{ Drug regimen } & \multirow[t]{2}{*}{ OR } & \multirow[t]{2}{*}{$P$-value } \\
\hline & & $\begin{array}{c}\text { ARB/ACEI - } \\
\text { containing }\end{array}$ & $\begin{array}{l}\text { Non-ARB/ACEI- } \\
\text { containing }\end{array}$ & & \\
\hline \multirow[t]{2}{*}{ Thrombin Time (secs) } & Deranged & 42 & 27 & $\begin{array}{c}1.56 \\
(0.70-3.46)\end{array}$ & 0.377 \\
\hline & Normal & 19 & 19 & & \\
\hline \multirow[t]{2}{*}{$\begin{array}{l}\text { Activated Partial Thromboplastin } \\
\text { Time(secs) }\end{array}$} & Deranged & 34 & 24 & $\begin{array}{c}1.15 \\
(0.54-2.49)\end{array}$ & 0.865 \\
\hline & Normal & 27 & 22 & & \\
\hline \multirow[t]{2}{*}{ Prothrombin Time (secs) } & Deranged & 37 & 24 & $\begin{array}{c}1.41 \\
(0.65-3.06)\end{array}$ & 0.496 \\
\hline & Normal & 24 & 22 & & \\
\hline \multirow[t]{2}{*}{ Platelet count (x 109/L) } & Deranged & 9 & 7 & $\begin{array}{c}0.96 \\
(0.33-2.82)\end{array}$ & 0.836 \\
\hline & Normal & 52 & 39 & & \\
\hline \multirow[t]{2}{*}{ D-dimer (ng/ml) } & Deranged & 18 & 9 & $\begin{array}{c}1.72 \\
(0.69-4.29)\end{array}$ & 0.343 \\
\hline & Normal & 43 & 37 & & \\
\hline
\end{tabular}

OR indicates Odds Ratio; (Confidence interval); ARB - Angiotensin Receptor Blockers; ACEI - Angiotensin-Converting

Enzyme Inhibitors

Deranged denotes prolonged or shortened times; raised or low counts

Agewall et al. ${ }^{[28]}$ showed a relationship between MA and fibrinogen by univariate analysis. This was in contrast to the findings in the present study which found no significant correlation between the parameters by univariate analysis. However, the present study demonstrated a positive correlation between commonly available haemostatic screening tests and MA, except with D-dimers by the regression model. This could imply the predictive value of abnormal haemostatic screening tests for the presence of MA and by implication, hypertension-related TOD. It has been postulated that individual parameters such as increased levels of plasma fibrinogen may act as an independent risk factor for cardiovascular disease, especially in post-menopausal females. [29] Also, reduced fibrinogen levels, as was found in our study, may reduce the cardiovascular risk of hypertensive patients. However, there is some uncertainty about causality because increased fibrinogen is not a consistent finding in hypertension and some studies have shown no significant differences in plasma fibrinogen levels between hypertensive and normotensive individuals, despite a strong correlation between plasma fibrinogen level and the presence and severity of TOD. [30,31]

The present study showed a reduced risk of derangements in TT, PT, and D-dimer in poorly controlled hypertension but an increase for aPTT and platelet counts. This observation had some congruence with increases in PT and aPTT levels as reported in a study conducted in Calabar, Nigeria, ${ }^{[32]}$ where the increases were shown to be related to the duration of hypertension. In the present study, the impact of duration of hypertension was demonstrated only on D-dimers levels for up to 10 years of the illness but the significance did not extend beyond 10 years. The other parameters studied did not show any significant relationship with the duration of illness. 
Table VI: Pattern of the haemostatic parameters in relation to the duration of hypertension

\begin{tabular}{|c|c|c|c|c|c|c|}
\hline Variables & $\begin{array}{l}\text { Duration of } \\
\text { hypertension } \\
\text { (years) }\end{array}$ & Level of & ariable & OR & $P$-value & Remark \\
\hline \multirow[t]{4}{*}{ D- Dimer (ng/ml) } & $<1$ & $\begin{array}{l}\text { Deranged } \\
0\end{array}$ & $\begin{array}{l}\text { Normal } \\
4\end{array}$ & - & & $\begin{array}{l}\text { Statistically significant } \\
\text { up to } 10 \text { years but not } \\
\text { beyond }\end{array}$ \\
\hline & $1-5$ & 5 & 29 & - & & \\
\hline & $6-10$ & 9 & 14 & - & 0.034 & \\
\hline & $>10$ & 13 & 33 & - & 0.129 & \\
\hline \multirow[t]{4}{*}{ Thrombin Time (secs) } & $<1$ & 4 & 0 & - & & No significant trend \\
\hline & $1-5$ & 17 & 17 & - & & \\
\hline & $6-10$ & 15 & 8 & - & & \\
\hline & $>10$ & 33 & 13 & - & 0.298 & \\
\hline \multirow[t]{4}{*}{ Platelet count $\left(x 10^{9} / \mathrm{L}\right)$} & $<1$ & 1 & 3 & 1.00 & & Ditto \\
\hline & $1-5$ & 6 & 28 & 0.64 & & \\
\hline & $6-10$ & 1 & 22 & 0.14 & & \\
\hline & $>10$ & 8 & 38 & 0.63 & 0.754 & \\
\hline \multirow{4}{*}{$\begin{array}{l}\text { Activated Partial } \\
\text { Thromboplastin Time } \\
\text { (secs) }\end{array}$} & $<1$ & 3 & 1 & 1.00 & & Ditto \\
\hline & $1-5$ & 20 & 14 & 0.48 & & \\
\hline & $6-10$ & 10 & 13 & 0.26 & & \\
\hline & $>10$ & 25 & 21 & 0.40 & 0.454 & \\
\hline \multirow[t]{4}{*}{ Prothrombin Time (secs) } & $<1$ & 3 & 1 & 1.00 & & Ditto \\
\hline & $1-5$ & 18 & 16 & 0.38 & & \\
\hline & $6-10$ & 11 & 12 & 0.31 & & \\
\hline & $>10$ & 29 & 17 & 0.57 & 0.649 & \\
\hline
\end{tabular}

OR - Odds Ratio

A study by Remkova and Kratochvilova, [33] also showed no statistically significant changes in haemostatic parameters (PT, aPTT, fibrinogen, D-dimers as well as plasminogen, antithrombin III, protein $C$ and free protein $S$ antigens, total fibrinolytic activity and fibrin monomers) among 23 patients with first and second stage hypertension, even following therapy with an angiotensin-converting enzyme inhibitor for one month. Sechi et al. had comparable findings but higher levels of plasma F1+2. [11] The levels of plasma fibrinogen and D-dimer were found to be related to diastolic blood pressure in patients with white coat hypertension and essential hypertension. [34]

These findings suggest abnormalities of haemorheology and thrombogenesis but they have not been consistent. It has further been suggested that it is unclear whether raised blood pressure promotes abnormal haemostasis or vice versa, and further studies would be required to determine true relationships. 
Ijei IP, et al.

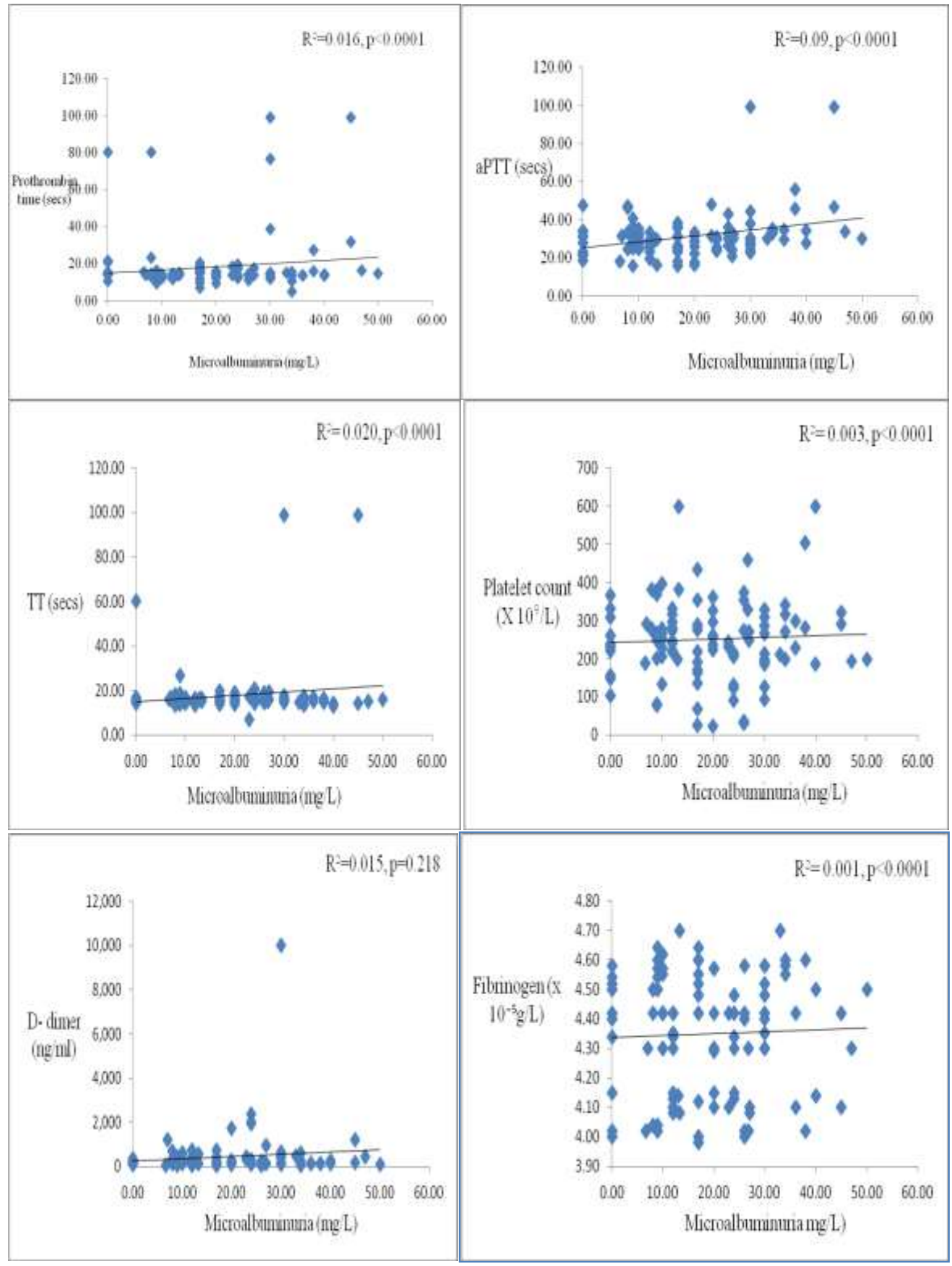

Figure 1: Regression analysis for microalbuminuria and haemostatic parameters 
In the present study, the risk of having derangements in haemostatic parameters was higher among patients on ARB/ACEIcontaining medications. This suggests that no protection was conferred by these medications though the findings were not statistically significant. This implies that the beneficial effects of these classes of drugs may not involve haemostatic mechanisms. However, the platelet counts were less likely to be deranged. The antiplatelet activity of ARBs and ACEIs has been reported [33,35] and in a study by Levy et al, platelet aggregation extent and rate were significantly altered by Losartan while perindopril was noted to have platelet inhibitory effect. [33,35]

A limitation of this study was the assessment of MA via on-the-spot urine sample collection though some guidelines suggest three (3) tests with $\geq 2$ showing positivity. The study was also confined to the hospital and a community-based population study would have been more reflective of the general population. Financial constraints deterred the use of tests of platelet and endothelial functions as well as exhaustive tests to establish TOD in all the usually affected organs. Prospective, community-based studies on a larger sample population may be more revealing with regards to the statistical significance of research findings and causality.

\section{Conclusion}

This study demonstrates a high prevalence of haemostatic abnormalities and microalbuminuria among hypertensives in Northern Nigeria. Abnormal haemostatic screening tests should raise suspicion of the presence of MA and the increased risk of TOD.
Authors' Contributions: IIP, BMH SBG, and MAI conceived and designed the study. IIP and YR did the literature review. IIP and $\mathrm{BMH}$ drafted the manuscript. All the authors did a critical revision of the manuscript for intellectual content and approved the final version of the manuscript.

Conflict of Interest: None.

Funding: Self-funded.

Publication History: Submitted 07 March 2019; Revised 08 May 2019; Accepted 01 June 2019.

\section{References}

1. Fisher NDL, Williams GH. Hypertensive vascular disease. In: Harrison's Principles of Internal medicine. Casper DL, Braunwald E, Fauci AS, Hauser SL, Longo DL, Jameson JL (Eds). 16 ${ }^{\text {th }}$ Edition. New York. McGraw-Hill Medical Publishing Division. 2005. Pp 14631480 .

2. Whitworth JA; World Health Organization, International Society of Hypertension Writing Group. 2003 World Health Organization (WHO)/ International Society of Hypertension (ISH) statement on management of hypertension. J Hypertens 2003; 21(11): 1983-1992. Available at http://www.ncbi.nlm.nih.gov/pubmed/145 97836?dopt=Abstract [Accessed 1st May 2019]

3. Giles TD. The new definition of hypertension. Program and abstracts of the 20th Annual Scientific Meeting of the American Society of Hypertension; May 1418, 2005; San Francisco, California. LateBreaking Clinical Trials. Available at http://www.medscape.com/viewarticle/50 5745 [Accessed 1st May 2019]

4. Aigbe A, Famodu AA. Haemorrheological and fibrinolytic activity in hypertensive Nigerians. Clin Hemorheol Microcirc 1999; 21(3-4): 415-420. 
5. Wolf-Maier $\mathrm{K}$, Cooper RS, Banegas JR, Giampaoli S, Hense H, Joffres M, et al. Hypertension prevalence and blood pressure levels in 6 European countries, Canada, and the United States. JAMA.2003; 289: 2363 2369. Available at http://jama.amaassn.org/cgi/content/full/289/18/2363.

[Accessed on 1st May 2019].

6. Adeloye D, Basquil C, Aderemi AV, Thompson JY, Obi FA. An estimate of the prevalence of hypertension in Nigeria: a systematic review and meta-analysis. J Hypertens 2014, 32: 000-000 [Cross check the pagination].

DOI:10.1097/HJH.0000000000000413

[Accessed on 28 th April 2019].

7. Ajayi IO, Sowemimo IO, Akpa OM, Ossai NE. Prevalence of hypertension and associated factors among residents of Ibadan-North Local Government Area of Nigeria. Niger J Cardiol 2016; 13: 67-75. DOI: 10.4103/0189-7969.165168 [Accessed on 28 ${ }^{\text {th }}$ April 2019].

8. Onwuchekwa AC, Chinenye S. Clinical profile of Hypertension at a University Teaching Hospital in Nigeria. Vasc Health Risk Manag 2010; 6: 511-516.

9. Ike SO, Ikeh VO. The prevalence of Diastolic Dysfunction in Adult Hypertensive Nigerians. Ghana Med J 2006; 40(2): 55-60.

10. Lip GYH. Hypertension, platelets and the endothelium. The "Thrombotic Paradox" of Hypertension (or 'Birmingham Paradox') Revisited. Hypertension 2003; 41: 199-200.

11. Sechi LA, Zingaro L, Catena C, Casaccio D, De Marchi S. Relationship of Fibrinogen Levels and Hemostatic Abnormalities with
Organ Damage in Hypertension. Hypertension 2000; 36: 978-985.

12. Aldo T, Scamardi R, Pizzoleo MA, Sottilotta G, Barbera N, Frisina N. Increased Indexes of Thrombin Activation in Advanced Stages of Hypertension. Haemostasis 2001; 31: 49-54.

13. Yusuff KB, Balogun OB. Pattern of Drug Utilization among Hypertensives in a Nigerian Teaching Hospital. Pharmacoepidemiol Drug Safety 2005; 1(1): 69-74.

14. Nabbaale J, Kibirige D, Ssekasanvu E, Sebatta ES, Kayima J, Lwabi P, et al. Microalbuminuria and left ventricular hypertrophy among newly diagnosed black African hypertensive patients: a crosssectional study from a tertiary hospital in Uganda. BMC Res Notes 2015 8: 198 DOI 10.1186/s13104-015-1156-2 [Accessed on 28th April 2019].

15. Hitha B, Pappachan JM, Balachandran Pillai $\mathrm{H}$, Sujathan P, Ramakrishna CD, Jayaprakash K, et al. Microalbuminuria in Patients with Essential Hypertension and its Relationship to Target Organ Damage: An Indian Experience. Saudi J Kidney Dis Transpl 2008; 19(3): 411-419.

16. Rodney CP, Desmond R, Roseman JM, Bell DSH, Vanichanan C, Acton RT. Prevalence and Risk factors of Microalbuminuria in a Cohort of African-American Women with Gestational Diabetes. Diabetes Care 2001; 24(10): 1764-1769. https://doi.org/10.2337/diacare.24.10.1764 [Accessed on 30th April 2019]

17. Gruden G, Cavallo-Perin P, Bazzan M, Stella S, Vuolo A, Pagano G. PAI-1, and Factor VII Activity are Higher in IDDM Patients with Microalbuminuria. Diabetes. 1994; 43(3): 426429. 
18. The Seventh Report of the Joint National Committee on Prevention, Detection, Evaluation, and Treatment of High Blood Pressure. NIH Publication No. 04-5230. August 2004: pp 11-12.

19. Isa AH; Hassan A; Garba Y; Ijei IP. Reference ranges of some haematological parameters in healthy Northern Nigerian adults. Jos J Med 2012; 6(3): 16-18.

20. Oladapo OO, Salako L, Sadiq L, Shoyinka K, Adedapo K, Falase AO. Target Organ Damage and Cardiovascular complications in Hypertensive Nigerian Yoruba Adults: a cross-sectional study. Cardiovasc J Afr 2012; 23: 379-384.

21. Laffan M, Manning $R$. Investigation of Haemostasis In: Dacie and Lewis Practical Haematology. Lewis SM, Bain BJ, Bates I (Eds.) Tenth Edition. Churchill Livingstone. An Imprint of Elsevier. Philadelphia.2006. pp 379-440.

22. Lewis SM, Tatsumi N. Collection and Handling of Blood In: Dacie and Lewis Practical Haematology. Lewis SM; Bain BJ; Bates I (ed.). Tenth Edition. Churchill Livingstone. An Imprint of Elsevier. Philadelphia.2006: 1-10.

23. Start4 Standardized Operating Procedures. Diagnostica Stago S.A.S. 9 Rue des Frères Chausson 92600 Asnières-Sur-Seine (France). Ref 26987-June 2002.

24. Jalal S, Sofi FA, Alai MS, Siddiqi MA, Bhat MA, Khan KA, et al. Prevalence of microalbuminuria in essential hypertension: A study of patients with mild to moderate hypertension. Indian J Nephrol. 2001; 11: 611.

25. Buch AC, Dharmadhikari M, Panicker NK, Chandanwale SS, Kumar H. Microalbuminuria: an early detector of diabetic and hypertensive nephropathy. Int J Basic Appl Med Sci 2012; 2(2): 218-225.
26. Badiger S, Sandeep HM, Talikoti SC, Biradar MS. A study of Microalbuminuria and target organ damage in patients with essential hypertension. Int J Biol Med Res. 2012; 3(1): 1351-1355.

27. Polonia J, Carmona J, Mendes E, Pisco L. Prevalence of Microalbuminuria in nondiabetic hypertensive patients attended by Portuguese GPs. Rev Port Cardiol 2007; 26(6): 637-644.

28. Agewall S, Fagerberg B, Attvall S, Ljungman S, Urbanavicius V, Tengborn I, Wickstrand Risk J. Microalbuminuria, insulin sensitivity and haemostatic factors in non-diabetic treated hypertensive men. J Internal Med 1995; 237(2): 195-203.

29. Tabak O, Gelisgen R, Uzun H, Kalender B, Balci H, Curgunlu A, et al. Hypertension and hemostatic/ fibrinolytic balance disorders. Clin Invest Med 2009; 32(6): E285-E292.

30. Sechi LA, Novello M, Colussi G, Di Fabio A, Chiuch A, Nadalini E, et al. Relationship of plasma renin with a prothrombotic state in hypertension: relevance for organ damage. Am J Hypertens 2008; 21: 1347-1353.

31. Catena C, Novello M, Lapena R, Baroselli S, Colussi G, Nadalini E et al. New risk factors for atherosclerosis in hypertension: focus on the prothrombotic state and lipoprotein (a). J Hypertens 2005; 23(9): 1617-1631. https://doi.org/10.1097/01.hjh.000078835.3 3976.e7 [Accessed on 30th April 2019].

32. Adaeze NN, Emeribe AU, Nasiru IA, Babayo A, Uko EK. Evaluation of prothrombin Time and Activated Partial Thromboplastin Time in Hypertensive Patients attending a Tertiary Hospital in Calabar, Nigeria. Adv Hematol 2014; Article ID 932039. http://dx.doi.org/10.1155/2014/932039 [Accessed on 30th April 2019].

33. Remkova A, Kratochvilova H. Effect of ACEI perindopril on haemostasis in essential 
Ijei IP, et al.

hypertension. Blood Coagul Fibrinolysis 2000; 11(7): 641-644.

34. Coban E, Ozdogan M, Akcit F. Levels of plasma fibrinogen and D-dimer in subjects with white-coat hypertension. J Human Hypertens 2004; 18: 291-292.
35. Levy PJ, Yunis C, Owen J, Brosnihan BK, Smith R, Ferrario CM. Inhibition of platelet aggregability by losartan in essential hypertension. Nefrologia 2002; XXII (2): 2428.

(C) 5 EY 8 NC
$\begin{array}{r}\text { This is an Open Access document licensed for distribution under the terms and conditions of } \\ \text { the Creative Commons Attribution License (http://creativecommons.org/licenses/by- } \\ \text { nc/4.0) This permits unrestricted, non-commercial use, reproduction and distribution in any } \\ \text { medium provided the original source is adequately cited and credited. }\end{array}$

